\title{
The Relationship Between Digital Egg Coloration and Egg Survival in Landlocked Fall Chinook
}

\author{
Holiday Robley \\ McNenny State Fish Hatchery, South Dakota Department of Game, Fish and Parks \\ 19619 Trout Loop, Spearfish, South Dakota, USA \\ Tel: 1-605-642-6920 \\ Michael E. Barnes (Corresponding author) \\ McNenny State Fish Hatchery, South Dakota Department of Game, Fish and Parks \\ 19619 Trout Loop, Spearfish, South Dakota, USA
}

Tel: 1-605-642-6920Ｅ-mail: mike.barnes@state.sd.us

Received: Nov. 6, 2018 Accepted: Dec. 6, 2018 Published: Dec. 11, 2018

doi:10.5296/ast.v7i1.14047 URL: https://doi.org/10.5296/ast.v7i1.14047

\begin{abstract}
Digital color values were collected from the eggs of 128 spawns from individual landlocked fall Chinook salmon Oncorhynchus tshawytscha females from Lake Oahe, South Dakota, USA, in 2008, 2009, 2015 and 2016. For all spawns, the mean (SE) a* value, a measure of red-green chromaticness, was 10.99 (0.27), and ranged from 3.98 to 18.71. Mean (SE) b* (yellow-green) was 20.27 (0.32), and ranged from 9.28 to 28.50. Mean (SE) L* (white-black) was $20.73(0.48)$, and ranged from 3.98 to 18.71. Egg total color index also showed considerable variation, with a mean (SE) of $23.05(0.37)$ and range from 11.70 to 31.64. Egg survival to the eyed-stage was weakly, but significantly, correlated to $b^{*}(r=0.206), L^{*}(r=$ 0.185), Chroma $(r=0.211)$, and Entire Color Index $(r=0.211)$. Spawns with no egg survival had eggs with significantly lower $a^{*}$ values compared to spawns where at least some of the eggs survived to the eyed stage. L*, $\mathrm{a}^{*}, \mathrm{~b}^{*}$, Chroma, and Entire Color Index varied significantly among the years, but Hue and egg survival to the eyed stage did not. The results of this study indicate a possible link between egg color and landlocked fall Chinook salmon egg survival, possibly due to differences in the diets of feral broodstock females or their ability to deposit bodily carotenoids in the developing eggs.
\end{abstract}

Keywords: Chinook Salmon, Oncorhynchus tshawytscha, Egg Color, Lake Oahe 


\section{Introduction}

Carotenoid pigments, such as astaxanthin, are chiefly responsible for the yellow-to-red coloration of salmonid eggs (Craik, 1985). These pigments cannot be synthesized by the fish and originate from dietary sources such as krill (Euphausids) and other crustaceans (Dissing et al., 2011). After ingestion, the pigments are deposited primarily in the muscle (Garner et al., 2010), and then incorporated into the ovaries and eggs during the breeding season (Kitahara, 1983; Torrissen and Torrissen, 1985; Garner et al., 2010).

Carotenoids are antioxidants (Maoka, 2011; Caramujo et al., 2012), and may benefit the eggs by providing some protection against low dissolved oxygen levels and elevated ammonia levels (Myers, 1994; Torrissen and Christiansen, 1995, de Carvalho and Caramujo, 2017). They may also protect against ultra-violet radiation (Craik, 1985; Caramujo et al., 2012), although Armstrong et al. (2000) suggested that they may offer little protection against sun damage. Carotenoids may also benefit salmonid eggs by being a precursor to the retinoids responsible for cell signalling during embryonic development (Kawakami et al., 2005; Bowles et al., 2006).

Several studies have examined a possible link between astaxanthin and salmonid egg quality. While Craik (1985) reported a positive relationship between salmonid egg carotenoids and survival to hatch, no such relationship was observed by Torrissen (1984), Craik and Harvey (1986), Tveranger (1986), and Christiansen and Torrissen (1997). All of these studies only examined carotenoid content however; no studies have specifically looked at quantifiable measures of actual egg color in relation to egg survival. Using a qualitative assessment of broodstock muscle and egg color, Beacham and Murray (1989) noted that eggs from red-fleshed Chinook salmon (Oncorhynchus tshawytscha) had more pigment than eggs from white-fleshed females, and also survived better at higher temperatures.

Fall Chinook salmon in Lake Oahe, South Dakota, USA, are a completely landlocked, freshwater population maintained entirely by hatchery production; there is no natural reproduction (Marrone and Stout, 1997; Lott et al., 1997). Compared to ocean-run Chinook salmon in their native range, Lake Oahe salmon are much smaller with dramatically different reproductive characteristics (Barnes et al., 2000; Young et al., 2016). Egg coloration is also dissimilar, with Oahe salmon typically producing predominantly yellow eggs, compared to the reddish coloration observed in eggs from ocean-run fish. These differences are likely due to differences in prey abundance and availability (Barnes et al., 2003; Young et al., 2016), but could be due to the inability of Oahe Chinook salmon to deposit carotenoids in their muscle tissue (Withler, 1986), and thus transfer less pigment to their ovaries and eggs (Beacham and Murray, 1989). Regardless, there is still considerable variation in Lake Oahe Chinook salmon egg color, which is not surprising given the large intraspecific variation in egg carotenoid content (Craik, 1985) and the numerous influences on carotenoid deposition (Myers, 1994).

Although astaxanthin can be the primary carotenoid pigment in salmon eggs, canthaxanthin can also be a major color source (Craik and Harvey, 1986; Torrissen and Christiansen, 1995). Both of these pigments are responsible for egg coloration, but nearly all of the afore-mentioned studies have looked exclusively at astaxanthin. Little research has been done 
on the actual quantifiable values of egg coloration. In addition, little research has been done using non-lethal techniques to quantify egg coloration. Given the global significance of salmonid aquaculture (FAO, 2018), a standardized, rapid, easy, and non-lethal method for egg coloration determination is clearly needed. Thus, the objective of this study was to describe, for the first time, the digital egg coloration of landlocked fall Chinook salmon eggs and examine any potential relationships between egg coloration and egg survival.

\section{Materials and Methods}

\subsection{Sample Collection}

Egg samples were obtained during the artificial spawning of feral landlocked fall Chinook salmon from Lake Oahe, South Dakota, on 14 October 2008, 27 October 2009, 23 October 2015, and 26 October 2016. Immediately after pneumatic egg stripping from a single female, a sample containing approximately $100 \mathrm{ml}$ of eggs was removed from the eggs expelled from a female, placed into a black cylinder for color measurement, and then returned to the egg mass where it originated for fertilization and further processing. Because preliminary analysis indicated extremely minimal variation (typically none) in egg coloration among samples of eggs from the spawn of an individual female, only one digital color value was used for each individual spawn.

\subsection{Coloration Analysis}

Digital color measurements of eggs from each spawn were taken with a HunterLab MiniScan XE Plus Colorimeter (HunterLab, Reston, Virginia, USA) using the CIELAB color scale (CIE 1976) to measure color. This color scale includes the values $\mathrm{L}^{*}, \mathrm{a}^{*}$, and $\mathrm{b}^{*}$, with $\mathrm{L}^{*}$ indicating white-to-black values (Choubert, 2010), $a^{*}$ indicating red-green chromaticness, and $b^{*}$ indicates yellow-blue chromaticness (Smith et al., 1992). The $\mathrm{L}^{*}, \mathrm{a}^{*}$, and $\mathrm{b}^{*}$ values were used to calculate Hue, Chroma, and the Entire Color Index (ECI) using the following formulas:

$$
\begin{gathered}
\text { Hue }=\arctan \left(b^{*} / a^{*}\right) \\
\text { Chroma }=\left[\left(a^{* 2}+b^{* 2}\right)^{1 / 2}\right]
\end{gathered}
$$

Entire Color Index $\left(\mathrm{ECI}_{\mathrm{i}}\right)=\mathrm{C}_{\mathrm{i}} * \cos \left(\mathrm{H}_{\mathrm{i}}-\mathrm{H}_{\text {mean }}\right)$, where $\mathrm{H}_{\text {mean }}=$ mean hue and $\left(\mathrm{C}_{\mathrm{i}}, \mathrm{H}_{\mathrm{i}}\right)=$ the chroma and hue values for each measurement (Pavlidis et al., 2006).

\subsection{Spawning and Egg Incubation}

Milt was collected from males, pooled in a container, and kept on ice until used. Eggs were expressed from each female into a suspended mesh net using compressed oxygen. The net containing the eggs was then placed in a plastic pan, with milt from the males added along with lake water for sperm activation and fertilization. After approximately one minute, the eggs were rinsed, poured into in a plastic bag with fresh water, placed in cooler, and allowed to water-harden for at least one hour.

The spawns from each female were maintained in their discrete plastic bags while transported in the coolers for $4 \mathrm{~h}$ to McNenny State Fish Hatchery, rural Spearfish, South Dakota, USA, 
and then during subsequent egg incubation. Upon arrival at the hatchery, each individual female spawn was disinfected in a $100 \mathrm{mg} / \mathrm{L}$ buffered free iodine solution for 10 minutes, inventoried by water displacement (Piper et al.,1982; Lahnsteiner et al., 1999) and then placed into discrete vertical-flow incubation trays (Marisource, Payallup, Washington, USA). Well water $\left(11^{\circ} \mathrm{C}\right.$; total hardness as $\mathrm{CaCO}_{3}, 360 \mathrm{mg} / \mathrm{L}$; alkalinity as $\mathrm{CaCO}_{3}, 210 \mathrm{mg} / \mathrm{L}$; pH 7.6; total dissolved solid, $390 \mathrm{mg} / \mathrm{L})$ was used throughout incubation. Daily formalin treatments using Paracide-F (37\% formaldehyde, 6 to $14 \%$ methanol, Western Chemical, Ferndale, Washington, USA) at a concentration of $1,667 \mathrm{mg} / \mathrm{L}$ for $15 \mathrm{~min}$ were administered with a Master-flex model 7524-00 microprocessor peristaltic pump (Cole-Parmer Instrument Company, Chicago, Illinois, USA). At the eyed stage of egg development (incubation day 28), dead eggs were removed and the viable eggs remaining re-inventoried by water displacement (Piper et al.1982; Lahnsteiner et al. 1999). The following formula was used to determine percent survival to the eyed development stage:

Survival $(\%)=100 \mathrm{x}$ (number of eyed eggs/initial egg number).

\subsection{Statistical Analysis}

Data was analyzed using the SPSS (9.0) statistical analysis program (SPSS, Chicago, Illinois, USA). Regression and correlation analysis was used to ascertain any possible relationships among the variables. Yearly data was analyzed using ANOVA and Tukey's mean comparison procedure. The significance level for all tests was predetermined at $P<0.05$.

\section{Results}

There was considerable variation in the color values among the eggs from individual female spawns (Table 1). Mean a* was 10.99, but ranged from 3.98 to 18.71. Similar variation was also observed between $\mathrm{L}^{*}$ and $\mathrm{b}^{*}$ values. The mean Entire Color Index value was 23.05, with a minimum of 11.70 and maximum of 31.64 . Mean survival to egg eye-up was $16.1 \%$ and ranged from 0 to over $75 \%$.

Table 1. Overall egg coloration statistics of landlocked fall Chinook salmon eggs ( $\mathrm{N}=128$ spawns from individual females, all years combined)

\begin{tabular}{lccc}
\hline & Mean (SE) & Minimum & Maximum \\
\hline $\mathrm{L}^{*}$ & $20.73(0.48)$ & 9.72 & 35.79 \\
$\mathrm{a}^{*}$ & $10.99(0.27)$ & 3.98 & 18.71 \\
$\mathrm{~b}^{*}$ & $20.27(0.32)$ & 9.28 & 28.50 \\
Hue & $1.08(0.01)$ & 0.72 & 1.38 \\
Chroma & $23.16(0.37)$ & 11.89 & 31.67 \\
Entire Color Index & $23.05(0.37)$ & 11.70 & 31.64 \\
Egg survival $(\%)$ & $16.10(1.57)$ & 0.00 & 75.87 \\
\hline
\end{tabular}

From spawns where none of the eggs survived, the mean a* value was significantly lower than in those eggs from spawns which experienced at least some egg survival (Table 2). No other significant difference in color measurements were observed between the two spawn 


\section{Macrothink}

groups. However, $P$ values for Chroma and Entire Color Index between the spawns with no eggs surviving and those with at least some egg survival were 0.059 and 0.052 respectively. Survival to eye-up was weakly but significantly correlated to $\mathrm{L}^{*}, \mathrm{~b}^{*}$, Chroma, and Entire Color Index (Table 3). In addition, there were several significant correlations among L*, $\mathrm{a}^{*}$, and $\mathrm{b}^{*}$ values as well as Chroma and ECI.

Table 2. Mean (SE) egg coloration characteristics from landlocked fall Chinook salmon spawns from individual females which either experienced total mortality or had at least some egg survival. Values followed by different letters are significantly different $(P<0.05)$.

\begin{tabular}{lccc}
\hline \multicolumn{4}{c}{ Egg Survival (\%) } \\
\hline & 0 & $>0$ & $\mathrm{P}$ \\
$\mathrm{L}^{*}$ & $20.02(0.96)$ & $20.87(0.55)$ & 0.510 \\
$\mathrm{a}^{*}$ & $9.69(0.78) \mathrm{z}$ & $11.26(0.27) \mathrm{y}$ & 0.027 \\
$\mathrm{~b}^{*}$ & $19.16(0.86)$ & $20.50(0.35)$ & 0.121 \\
Hue & $1.11(0.03)$ & $1.07(0.01)$ & 0.087 \\
Chroma & $21.62(1.02)$ & $23.48(0.39)$ & 0.059 \\
Entire Color Index & $21.46(1.03)$ & $23.28(0.39)$ & 0.052 \\
Egg Survival $(\%)$ & 0 & $19.4(1.7)$ & \\
$\mathrm{N}$ & 22 & 106 & \\
\hline
\end{tabular}


Table 3. Significant correlations between landlocked fall Chinook salmon egg coloration components themselves and also between egg coloration and egg survival $(P<0.05)$.

\begin{tabular}{cccc}
\hline Variable 1 & Variable 2 & $P$ & $\mathrm{r}$ \\
\hline $\mathrm{L}^{*}$ & $\mathrm{a}^{*}$ & 0.000 & 0.536 \\
$\mathrm{~L}^{*}$ & $\mathrm{~b}^{*}$ & 0.000 & 0.693 \\
$\mathrm{~L}^{*}$ & Chroma $^{*}$ & 0.000 & 0.718 \\
$\mathrm{~L}^{*}$ & ECI $^{1}$ & 0.000 & 0.714 \\
$\mathrm{a}^{*}$ & $\mathrm{~b}^{*}$ & 0.000 & 0.568 \\
$\mathrm{a}^{*}$ & Hue & 0.000 & -0.718 \\
$\mathrm{a}^{*}$ & Chroma & 0.000 & 0.767 \\
$\mathrm{a}^{*}$ & ECI & 0.000 & 0.775 \\
$\mathrm{~b}^{*}$ & Chroma & 0.000 & 0.962 \\
$\mathrm{~b}^{*}$ & ECI & 0.000 & 0.960 \\
Chroma & ECI & 0.000 & 0.999 \\
Egg survival $(\%)$ & $\mathrm{L} *$ & 0.037 & 0.185 \\
Egg survival $(\%)$ & $\mathrm{b}^{*}$ & 0.020 & 0.206 \\
Egg survival $(\%)$ & Chroma & 0.017 & 0.211 \\
Egg survival $(\%)$ & ECI & 0.017 & 0.211 \\
\hline
\end{tabular}

${ }^{1} \mathrm{ECI}=$ Entire Color Index

Egg color varied significantly from year to year (Table 4). L*, a*, b*, Chroma and Entire Color Index were generally the highest in 2015. In contrast, values were generally the lowest in 2009 and 2016. Hue was similar in all four of the years. There was no significant difference in egg survival among the years.

Table 4. Mean (SE) landlocked fall Chinook salmon egg color and egg survival values for spawns of individual females for four years. Means followed by different letters are significantly different $(P<0.05)$.

\begin{tabular}{lcrrr}
\hline \multicolumn{5}{c}{ Year } \\
\hline $\mathrm{L}^{*}$ & 2008 & 2009 & 2015 & 2016 \\
$\mathrm{a}^{*}$ & $21.54(0.79) \mathrm{zy}$ & $18.14(0.96) \mathrm{x}$ & $25.57(1.40) \mathrm{z}$ & $19.75(0.64) \mathrm{yx}$ \\
$\mathrm{b}^{*}$ & $13.38(3.12) \mathrm{z}$ & $10.32(0.40) \mathrm{x}$ & $15.25(0.69) \mathrm{z}$ & $7.97(0.43) \mathrm{w}$ \\
Hue & $21.62(0.44) \mathrm{z}$ & $17.65(0.55) \mathrm{y}$ & $23.17(0.77) \mathrm{z}$ & $18.90(0.60) \mathrm{y}$ \\
Chroma & $1.05(0.01) \mathrm{y}$ & $1.04(0.01) \mathrm{y}$ & $0.99(0.01) \mathrm{y}$ & $1.17(0.02) \mathrm{z}$ \\
Entire Color Index & $24.89(0.46) \mathrm{z}$ & $20.48(0.64) \mathrm{y}$ & $27.77(0.96) \mathrm{z}$ & $20.66(0.60) \mathrm{y}$ \\
Egg Survival $(\%)$ & $18.12(2.37) \mathrm{z}$ & $13.37(3.08) \mathrm{z}$ & $19.62(6.26) \mathrm{z}$ & $13.38(3.12) \mathrm{z}$ \\
\hline
\end{tabular}

\section{Discussion}

The results from this first examination of color in landlocked fall Chinook salmon eggs are intriguing and raise several questions. Why was there such a large amount of variation (nearly 
five-fold) in individual spawn egg color? Why was there such large year-to-year variation in egg color? And why was there an apparent, though weak, relationship between digital egg color and egg survival?

Myers (1994) stated that carotenoid levels in wild salmonids vary due to differences in prey, fish size, stage of maturity, and pigment metabolism. With regard to Chinook salmon in Lake Oahe, prey type and availability likely explain most of the intraspecific and year-to-year variation in egg color. Rainbow smelt Osmerus mordax have traditionally been considered the primary prey source for Oahe salmon (Hill, 1997; Barnes et al., 2003). However smelt numbers fluctuate dramatically from year-to-year (Stone and Nealson, 1990; Young et al., 2016). During one year of low rainbow smelt abundance, the diets of Oahe Chinook salmon consisted of 58\% Ephemeroptera, 22\% miscellaneous zooplankton and only $20 \%$ rainbow smelt (Hanten and Stout, 1999; Barnes et al., 2000). In addition, lake herring Coregonus artedi and gizzard shad Dorosoma cepedianum have also become salmon prey items (Young et al., 2016). These frequent and rapid dietary shifts are likely the major contributor to differences in egg coloration. Lake Oahe salmon may also have relatively unique genetics (Young et al., 2016), which may impact pigment metabolism and ultimately egg color (Withler, 1986; Myers, 1994).

The positive correlation between egg coloration values and survival, as well as the significantly greater $\mathrm{a}^{*}$ (red) values in spawns which experienced at least some egg survival, may be temperature related. Chinook salmon in Lake Oahe experience elevated temperatures during egg development and maturation (Young et al., 2016; Doyle et al., 2017). In addition, spawning water temperatures are frequently above $15^{\circ} \mathrm{C}$. This hypothesis is supported by Beacham and Murray (1989) who reported more heavily pigmented Chinook salmon eggs survived better at higher temperatures. It is also possible that increased red coloration, most likely due to increased carotenoid pigmentation, may be positively influencing egg survival if the eggs are being subjected to low dissolved oxygen or high ammonia levels during spawning and hatchery incubation (Myers, 1994; Torrissen and Christiansen, 1995; de Carvalho and Caramujo, 2017). However, it is unlikely that such situations are occurring. Lastly, if Lake Oahe egg coloration values indicate low dietary carotenoid levels, that in itself may be directly impacting egg survival rates (Myers 1994).

The egg survival values observed during the multiple years of this study were typical of Lake Oahe Chinook salmon eggs (Barnes et al., 2000; Young et al., 2016). This poor survival has been attributed to nutritional limitations, elevated spawning water temperatures, and genetic issues (Young et al., 2016; Doyle et al., 2017). The significant difference in a* values between those spawns which experienced total mortality versus those where at least some of the eggs survived is of particularly interest. Doyle et al. (2017) reported lower egg thiamine levels in landlocked fall Chinook salmon spawns which did not survive. Huysman et al. (2018) observed that female salmon producing completely non-viable spawns may have been held for a slightly longer period of time prior to spawning, and that their spawns had relatively fewer eggs. It is possible that the decrease in $a^{*}$ was associated with egg aging, in addition to being potentially influenced by dietary differences. 
Because this is the first study to digitally quantify egg coloration, it is difficult to compare the results to other studies which have used either qualitative assessments of egg color or measured the actual concentrations of a single carotenoid pigment (Torrissen, 1984; Craik, 1985; Craik and Harvey, 1986; Tveranger, 1986; Christiansen and Torrissen, 1997). Additional research is needed to determine the relationship between digital egg color and specific egg pigment concentrations, either alone or in combination. While the results of this study likely have general applicability, they may also be species, or even population, specific given the numerous influences on egg carotenoid levels. Thus, further investigation into egg coloration of other salmonids and other Chinook salmon populations would be desirable.

\section{Conclusion}

This study describes the digital egg coloration of landlocked fall Chinook salmon eggs, as well as the relationship between egg coloration and survival. In addition, it details the considerable year-to-year, and individual female spawn-to-spawn, variation in egg color. Because this is the first to use digital color technology, it provides the basis for further investigations with this population of Chinook salmon, as well as with other populations and different fish species.

\section{Acknowledgement}

We thank Eric Krebs, Patrick Nero, and all of the other individuals involved with salmon spawning and egg incubation for their assistance with this study.

\section{References}

Armstrong, T. N., Cronin, T. W., \& Bradley, B. P. (2000). Microspectrophotometric analysis of intact chromatophores of the Japanese medaka, Oryzias latipes. Pigment Cell and Melanoma Research, 13, 116-119. https://doi.org/10.1034/j.1600-0749.2000.130210.x

Barnes, M. E., Hanten, R. P., Cordes, R. J., Sayler, W. A., \& Carreiro, J. (2000). Reproductive performance of inland fall Chinook salmon. North American Journal of Aquaculture, 62, 203-211. https://doi.org/10.1577/1548-8454(2000)062<0203:RPOIFC>2.3.CO;2

Barnes, M. E., Zehfus, M. H., Schumacher, J. A., Stock, S, Farrokhi, F., \& Nutter, R. L. (2003). Maternal liver and egg thiamine concentrations in Chinook salmon from Lake Oahe, South Dakota. Prairie Naturalist, 35, 113-116.

Beacham, T. D., \& Murray, C. B. (1989). Variation in developmental biology of sockeye salmon (Oncorhynchus nerka) and Chinook salmon (O. tshawytscha) in British Columbia. Canadian Journal of Zoology, 67, 2081-2089. https://doi.org/10.1139/z89-297

Bowles, J., Knight, D., Smith, C., Wilhelm, D., Richman, J., Mamiya, S., \& Koopman, P. (2006). Retinoid signaling determines germ cell fate in mice. Science, 312, 596-600. https://doi.org/10.1126/science.1125691

Caramujo, M. J., de Carvalho, C. C., Silva, S. J., \& Carman, K. R. (2012). Dietary carotenoids regulate astaxanthin content of copepods and modulate their susceptibility to UV light and copper toxicity. Marine Drugs, 10, 998-1018. https://doi.org/10.3390/md10050998 


\section{Macrothink}

Aquatic Science and Technology

ISSN 2168-9148

2019, Vol. 7, No. 1

Choubert, G. (2010). Response of rainbow trout (Oncorhynchus mykiss) to varying dietary astaxanthin/ canthaxanthin ratio: colour and carotenoid retention of the muscle. Aquaculture Nutrition, 16, 528-535. https://doi.org/10.1111/j.1365-2095.2009.00692.x

Christiansen, R., \& Torrissen, O. J. (1997). Effects of dietary astaxanthin supplementation on fertilization and egg survival in Atlantic salmon (Salmo salar L.). Aquaculture, 153, 51-62. https://doi.org/10.1016/S0044-8486(97)00016-1

CIE (Commission Internationale de L'Eclairage). (1986). Colorimetry. CIE Publication 15.2, 2nd ed., Vienna, Austria.

Craik, J. C. A. (1985). Egg quality and egg pigment content in salmonid fishes. Aquaculture, 47, 61-88. https://doi.org/10.1016/0044-8486(85)90008-0

Craik, J. C. A., \& Harvey, S. M. (1986). The carotenoids of eggs of wild and farmed Atlantic salmon, and their changes during development to the start of feeding. Journal of Fish Biology, 29, 549-565. https://doi.org/10.1111/j.1095-8649.1986.tb04972.x

de Carvalho, C. C. C. R., \& Caramujo, M. J. (2017). Carotenoids in aquatic ecosystems and aquaculture: a colorful business with implications for human health. Frontiers in Marine Science, 4, 1-13. https://doi.org/10.3389/fmars.2017.00093

Dissing, B. S., Nielsen, M. E., Ersboll, B. K., \& Frosch, S. (2011). Multispectral imaging for determination of astaxanthin concentration in salmonids. PLoS ONE, 6(5), e19032. https://doi.org/10.1371/journal.pone.0019032

Doyle, A., Barnes, M. E., Kientz, J. L., \& Zehfus, M. H. (2017). Landlocked fall Chinook salmon maternal liver and egg thiamine levels in relation to reproductive characteristics. Open Fish Science Journal, 10, 23-32. https://doi.org/10.2174/1874401X01710010023

FAO (Food and Agriculture Organization of the United Nations). (2018). Fishery and Aquaculture Statistics 2016 Yearbook. Accessed online on 5 December 2018 at http://www.fao.org/3/i9942t/I9942T.pdf

Garner, S. R., Neff, B. D., \& Bernards, M. A. (2010). Dietary carotenoid levels affect carotenoid and retinoid allocation in female Chinook salmon Oncorhynchus tshawytscha. Journal of Fish Biology, 76, 1474-1490. https://doi.org/10.1111/j.1095-8649.2010.02579.x

Hanten, R. P., \& Stout, D. A. (1999). 1998 Whitlocks Bay spawning and imprinting station annual report. South Dakota Game, Fish amd Parks Annual Report 99-10, Pierre.

Hill, T. D. (1997). Life history and bioenergetics of Chinook salmon in Lake Oahe, South Dakota. Dissertation. South Dakota State University, Brookings, USA.

Huysman, N., Voorhees, J. M., Meyer, H., Krebs, E., \& Barnes, M. E. (2018). Characteristics of landlocked fall Chinook salmon producing either viable or completely non-viable eggs. International Journal of Fisheries and Aquatic Studies 6(6), 86-88.

Kawakami, Y., Raya, Á., Raya, R. M., Rodríguez-Esteban, C., \& Belmonte, J. C. I. (2005). Retinoic acid signally links left-right asymmetric patterning and bilaterally symmetric 
somitogenesis in zebrafish embryo. Nature, 435, 165-171.

https://doi.org/10.1038/nature03512

Kitahara, T. (1983). Behavoir of carotenois in the chum salmon (Oncorhynchus keta) during anadromous migration. Comparative Biochemistry and Physiology B, 76, 97-101. https://doi.org/10.1016/0305-0491(83)90177-3

Lahnsteiner, F., Weismann, T., \& Patzner, R. A. (1999). Physiological and biochemical parameters for egg quality determination in Lake Trout, Salmo trutta lacustris. Fish Physiology and Biochemistry, 20, 375-388. https://doi.org/10.1023/A:1007715621550

Lott, J., Marrone, G., \& Stout, D. (1997). Influence of size-and-date at stocking, imprinting attempts and growth on initial survival, homing ability, maturation patterns and angler harvest of Chinook salmon in Lake Oahe, South Dakota. South Dakota Department of Game, Fish and Parks Progress Report 97-20, Pierre.

Maoka, T. (2011). Carotenoids in marine animals. Marine Drugs, 9, 278-293. https://doi.org/10.3390/md9020278

Marrone, G. M., \& Stout, D. A. (1997). 1997 Whitlocks Bay Spawning Station Annual Report. South Dakota Department of Game, Fish and Parks Annual Report Number 97-19. Pierre.

Myers, S. P. (1994). Developments in world aquaculture, feed formulations, and role of carotenoids. Pure and Applied Chemistry, 66, 1069-1076.

https://doi.org/10.1351/pac199466051069

Pavlidis, M., Papandroulakis, N., \& Divanach, P. (2006). A method for the comparison of chromaticity parameters in fish skin: Preliminary results for coloration pattern of red skin Sparidae. Aquaculture, 258, 211-219. https://doi.org/10.1016/j.aquaculture.2006.05.028

Piper, R. G., McElwain, I. B., Orme, L. E., McCraren, J. P., Fowler, L. G., \& Leonard, J. R. (1982). Fish Hatchery Management. U.S. Fish and Wildlife Service, Washington, D. C.

Smith, B., Hardy, R. W., \& Torrissen, O. J. (1992). Synthetic astaxanthin deposition in pan-sized coho salmon (Oncorhynchus kisutch). Aquaculture, 104, 105-119.

https://doi.org/10.1016/0044-8486(92)90141-7

Stone, C. C., \& Nealson, P. (1990). An estimate of abundance and distribution of rainbow smelt in Lake Oahe reservoir using hydroacoustic techniques. (1988-1989) South Dakota Department of Game, Fish and Parks Progress Report 90-8. Pierre, USA.

Torrissen, K. R., \& Torrissen, O. J. (1985). Protease activities and carotenoid levels during the sexual maturation of Atlantic salmon (Salmo salar). Aquaculture 50, 113-122. https://doi.org/10.1016/0044-8486(85)90157-7

Torrissen, O. J., \& Christiansen, R. (1995). Requirements for carotenoids in fish diets Journal of Applied Ichthyology, 11, 225-230. https://doi.org/10.1111/j.1439-0426.1995.tb00022.x

Torrissen, O. J. (1984). Pigmentation of salmonids - effect of carotenoids in eggs and start-feeding diet on survival and growth rate. Aquaculture, 43, 185-193. 
https://doi.org/10.1016/0044-8486(84)90021-8

Tveranger, B. (1986). Effect of pigment content in broodstock diet on subsequent fertilization rate, survival and growth rate of rainbow trout (Salmo gairdneri) offspring. Aquaculture, 53, 85-93. https://doi.org/10.1016/0044-8486(86)90278-4

Withler, R. E. (1986). Genetic variation in carotenoid pigment desposition in the red-fleshed and white-fleshed Chinook salmon (Oncorhynchus tshawytscha) of Quensel River, British Columbia. Canadian Journal of Genetics and Cytology, 28, 587-594.

https://doi.org/10.1139/g86-086

Young, K. L., Barnes, M. E., \& Kientz, J. L. (2016). Reproductive characteristics of landlocked fall Chinook salmon from Lake Oahe, South Dakota. Prairie Naturalist, 48, 79-86.

\section{Copyrights}

Copyright for this article is retained by the author(s), with first publication rights granted to the journal.

This is an open-access article distributed under the terms and conditions of the Creative Commons Attribution license (http://creativecommons.org/licenses/by/4.0/) 